\title{
Academic Performance in Mining Areas: The Case of Selected Junior High Schools in the Atwima Kwanwoma District, Ghana
}

\author{
${ }^{1}$ Robert Andrews Ghanney ${ }^{\mathbf{2} J o h n ~ P a u l ~ D u g h a n ~ a n d ~}{ }^{\mathbf{3}}$ Joseph Bentil \\ (Department of Basic Education, University of Education, Winneba, GHANA)
}

\begin{abstract}
This study sought out to investigate the influence of illegal mining on academic performance of junior high school pupils in the Atwima Kwanwoma District in the Ashanti Region of Ghana. In order to achieve the purpose of the study, a convergent mixed method design was employed. The sample size for the quantitative study was 105 , comprising 70 pupils and 35 parents. In the qualitative phase, a sample size of 8 comprising 4 pupils and 4 parents were employed. The researchers used questionnaire and interview guide as the primary tools for collecting data. The questionnaire and interview guide were employed to collect quantitative and qualitative data respectively. The quantitative data were analysed using the version 22 of the Statistical Product and Service Solution, SPSS whereas the qualitative data were analysed using the thematic approach. Among the findings of the study, it was revealed that, illegal mining activities contributed statistically significantly to pupils' poor academic performance in Social Studies. The study recommended that the Directorate of the Ghana Education Service at Atwima Kwanwoma District and traditional leaders should be in constant dialogue with members of the communities, especially parents, to appreciate the value of formal education in order to ensure that their children stay in school and study. It was suggested that further research be conducted in other basic schools in the country where illegal mining activities are carried out to give the general overview regarding the influence of illegal mining activities on academic performance of junior high school pupils and to come out with holistic approach in curbing the situation.
\end{abstract}

Keywords: MINING, ACADEMIC PERFORMANCE, JUNIOR HIGH SCHOOL, PUPILS

\section{Introduction}

Mining is the extraction of minerals and precious metals from the earth (Adu-Gyamfi, 2014). Some minerals extracted from the earth are diamond, bauxite, manganese and gold. With a reasonably well-known and attractive mineral resource base, a significant mining investment has been attracted into the country over some 20 years of stable multi-party democracy. The mining sector has therefore been an important part of our economy, with gold accounting for over $90 \%$ 
of the sector (Akabzaa, 2007). Ghana is the second largest gold producer in Africa and the 9th largest producer in the world. In Ghana, small-scale mining mostly of diamond and gold has expanded dramatically in recent years contributing significantly to the improvement of local economies and gross foreign exchange (Amankwah \& Anim-Sackey, 2003). Small-scale mining may be legal (registered) or illegal (not registered). Where they are registered there is some level of supervision, hence moderate consideration for environmental concerns (Iddirisu \& Tsikata, 1998). Nevertheless, much destruction is done to the environment in the sense that activities done here are more vigorous and relatively higher. In situations where small scale mining activities are not registered, there is no monitoring, hence these miners are left unchecked, and the degraded environment receives no remediation. Over the past years, Ghana has been confronted with the negative effects of illegal mining in her communities. Ankutse (2015) in a study noted that, some districts (e.g., Asutifi) are experiencing the repercussions of a somewhat negative influence of mining on children's performance, enrolment and retention in schools. According to Ankutse (2015), the major communities within the district have raised great public outcries on the seriously mining-led problems that threaten to destroy the human capital of the communities in the near future.

In Ghana, a number of educational initiatives have been put in place to deal with adverse effects on mining activities. This includes Free Compulsory Universal Basic Education (FCUBE) and Capitation Grants. Other programmes like Free Transportation for school children in the Metro Mass Transit Busses, Free school uniforms and other learning materials were given free to children, all with the aim of promoting children's education which also serve as an expressway for removing children from mining-led child labour. All these educational policies and programmes are good in their places but as to whether they have brought significant educational changes in mining communities of Ghana remains an unanswered question. This research, therefore, sought to investigate the influence of illegal mining on academic performance of junior high school pupils in the Atwima Kwanwoma District in the Ashanti Region of Ghana.

\section{Statement of the Problem}

Many developing countries in sub-Saharan Africa with abundant resources are confronted with the issue of 'resource curse' (Ankutse, 2015). Illegal mining activities which is locally known in Ghana as galamsey or mechanism to extract gold and other mineral resources appears to be on the rise with its attendant effects especially in Atwima Kwanwoma District in the Ashanti Region of Ghana. Atwima Kwanwoma District in the Ashanti Region of Ghana appears to be one of such districts that is experiencing the repercussions of a somewhat negative influence of mining on children's performance. The number of galamseys in Ghana is unknown, but it is believed to be from 20,000 to 50,000 and most of them operate in communities where there are substantial reserves of gold deposits and usually within the environs of the larger mining companies (Annan, 2015; Adjei, 2017). Most young people, including children, are notable for engaging in such acts with the idea of getting quick money. According to Annan (2015), many children of school going age have abandoned classrooms and are now into full-scale illegal mining activities, in view of the monetary benefits that come with these activities, despite the associated risks. Owusu and Dwomoh (2012) in a study on the impact of illegal mining on the 
Ghanaian youth showed that, illegal mining activities have negative impacts on the youth's school attendance and academic performance. Atwima Kwanwoma District of Ghana appears to be one of such districts with illegal mining activities. However, it appears little attention has been paid to the influence of illegal mining activities on academic performance of pupils in the Atwima Kwanwoma District in the Ashanti Region of Ghana.

\section{Purpose of the Study}

The purpose of the study was to investigate the influence of illegal mining on academic performance of junior high school pupils in the Atwima Kwanwoma District in the Ashanti Region of Ghana.

The objective of the study was to:

Determine the extent to which illegal mining activities influence the academic performance of junior high pupils in Atwima Kwanwoma District in the Ashanti Region of Ghana.

\section{Research Question}

The study was guided by the research question below:

To what extent do illegal mining activities influence the academic performance of junior high school pupils in Atwima Kwanwoma District in the Ashanti Region of Ghana?

\section{Hypothesis}

The study also tested the hypothesis below:

Ho1: Junior High School pupils' academic performance is not influenced by the illegal mining activities in Atwima Kwanwoma District in the Ashanti Region of Ghana.

Ha1: Junior High School pupils' academic performance is influenced by the illegal mining activities in Atwima Kwanwoma District in the Ashanti Region of Ghana.

\section{Significance of the Study}

The attraction of children into mining sites can draw children out of schools and may jeopardize the human resource capacity of the study area in the near or distant future. This study would help to uncover the real causes and pattern of the falling standards of education in the face of vigorous mining activities. The study would add more information to existing literatures on the measures to be taken to remove or reduce the movement of children into the mining sites. It would also help to check whether efforts to provide educational support have proved sufficient in discouraging children from engaging in arduous mining activities. 


\section{Delimitation of the Study}

There are specific delimitations to this study. The primary delimitation is that; the study is meant to focus on only academic performance of pupils in Social Studies. Also, only perspectives of parents who have their children engaged in related illegal mining activities at the Junior High School level were explored.

\section{Operational Definition of Terms}

Academic Achievement: A learning outcome that shows the level of progress that pupils are making at the different level of progression

\section{RELATED LITERATURE REVIEW}

This is made up of theoretical and empirical reviews

\section{Theoretical Review}

Maslow's hierarchy of needs theory has categorized individual needs into five categories (Maslow, 1971). These are: Physiological, Safety, Love/Belonging, Self- esteem, and Selfactualization. These needs are hierarchical and begin with the physiological through selfactualization. Maslow's hierarchy of needs theory has been criticized based on the fact that individuals can have affection even if their physiological needs are not fully satisfied. For authors such as Jackson et al. (2004), Maslow's theory over-emphasizes the individualistic nature of needs-satisfaction and understates the importance of society, culture, and the natural environment by treating these as secondary in importance to individual motivation. Alongside some of these criticisms is the argument that individuals can pursue multiple needs at the same time (Anney, 2014).

Alongside the theory on needs, this study also uses the concept of sustainable livelihoods to discuss how people draw on different assets and undertake different activities to respond to variations in their livelihoods due to the incidence of mining. Hilson and Potter (2003) defined a livelihood system as comprising the capabilities, assets (including both material and social resources), and activities required for a means of living. A livelihood strategy connotes a combination of assets and activities to make a living. A livelihood system or strategy encompasses not only activities that generate income but many other kinds of elements, including cultural and social choices (Ellis, 2000). For Ellis (2000), sustainability is achieved when a livelihood "can cope with and recover from stresses and shocks and maintain or enhance its capabilities and assets both now and in the future, while not undermining the natural resource base." In the context of mining, the stresses and shocks refer to the changes that occur at a setting as a result of mining related activities. Most often mining communities encounter displacements from farmlands and this has consequences for livelihoods and level of vulnerability, especially those who are unable to cope or adapt to the changes brought in by mining. The outcomes in terms of vulnerability will have consequences for the level of needs and development. 


\section{Mining Activities and their Influence on Pupils' Academic Performance at School}

Academic performance refers to how students deal with their studies and how they cope with or accomplish different tasks given to them by their teachers. It can as well be said to be the ability for pupils to study and remember facts and being able to communicate their knowledge either verbally or written down on paper. The concept of poor academic performance varies in its definition. Diaz (2003) considers poor academic performance or academic failure as the situation in which the subject does not attain the expected achievement according to his or her abilities, resulting in an altered personality which affects all other aspects of life. Some indicators of poor academic performance are low Grade Point Average (GPA), poor class participation, poor coordination among teachers and students, and absenteeism. Asiedu-Addo (2009) and Howard (1994) in a study proposed several reasons for children's low performance among which are medical problems, below average intelligence, specific learning disability, emotional problems and environmental causes. A study by Adu-Gyamfi (2014) revealed that illegal mining activities undertaken by pupils do have negative effect on academic performance and it was established that pupils who come to school regularly perform tremendously while the absentee pupils perform poorly.

\section{METHODOLOGY}

\section{Researchers' Methodological Position}

Research paradigm is the philosophical or motivation for undertaking a study (Cohen, Manion \& Morrison, 2007). The study is located basically in the pragmatic paradigm. The mixed method approach was employed in the study due to the nature of the research questions and advantages derived from applying two different approaches in garnering the required data. This design, according to Creswell (2012), involved combining or integration of qualitative and quantitative research data in a research study.

\section{Research Design}

A research design is a plan that describes the conditions and procedures for collecting and analyzing data (McMillan \& Schumacher, 2010). The study employed convergent mixed method design. Convergent mixed method design is an approach to research where the researcher collects both quantitative and qualitative data, analyses them separately, and then compares the results to see if the findings confirm or disconfirm each other (Creswell, 2012). The key assumption of this approach is that both quantitative and qualitative data provide different types of information, often detailed views of participants qualitatively and scores on instruments quantitatively, and together they yield results that should be the same.

\section{Setting}

The study was conducted in some selected public junior high schools in the Atwima Kwanwoma District in the Ashanti Region of Ghana. Atwima Kwanwoma District is one of the two hundred and sixteen (216) Districts in Ghana and one of the thirty (30) Districts in the Ashanti Region. 


\section{Population}

A target population is the larger group that one aspires to apply findings (Yin, 2014). The target population of the study was all pupils at the public junior high schools, and parents, in the Atwima Kwanwoma District in the Ashanti Region of Ghana. The accessible population of this study was all the pupils at Nweneso 1 D/A, Nweneso 2 D/A, and Nweneso 3 D/A Junior High Schools, and parents, in the Atwima Kwanwoma District in the Ashanti Region of Ghana.The population distribution of pupils in the three selected schools were explored and the details are illustrated in Table 1.

Table 1: Population Distribution of pupils in the three selected schools in Atwima Kwanwoma District

\begin{tabular}{llll}
\hline School & Male & Female & Total \\
\hline Nweneso 1 D/A & 106 & 81 & 187 \\
Nweneso 2 D/A & 84 & 46 & 130 \\
Nweneso 3 D/A & 39 & 38 & 77 \\
\hline Total & $\mathbf{2 2 9}$ & $\mathbf{1 6 5}$ & $\mathbf{3 9 4}$ \\
\hline
\end{tabular}

Source: District Education Directorate (2019).

From Table.1, the data show that, the population distribution of pupils in Nweneso 1 D /A JHS was one hundred and eighty-seven (187), comprising of one hundred and six (106) males and eighty-one (81) females. Nweneso 2 D/A JHS had a population distribution of eighty-four (84) males, and forty-six (46) females, making a total of one hundred and thirty (130) pupils. The population distribution of pupils' in Nweneso 3 D/A JHS was seventy-seven (77), comprising of thirty-nine (39) males, whereas thirty-eight (38) were females.

\section{Sample}

A sample is a small portion of a target population (Yin, 2014). In the study, a sample size of 105 comprising 70 pupils and 35 parents were used in the quantitative phase. According to AsamoahGyimah and Duodu (2007), a sample of $10 \%$ to $30 \%$ to the accessible size is desirous in quantitative study. Hence, $27 \%(\mathrm{n}=105)$ of the accessible population was deemed appropriate for the study. In the qualitative phase, a sample size of 8 comprising 4 pupils and 4 parents were employed. Yin (2014) proposed six sources of evidences in qualitative study, therefore, 8 participants are deemed appropriate.

\section{Sampling Technique}

Different sampling techniques were employed to select respondents for the study. Purposive sampling was used to select three junior high schools namely: Nweneso 1 D/A, Nweneso 2 D/A, and Nweneso 3 D/A. These schools were located at the illegal mining communities and that; they receive the immediate impact of the mining activities in the Atwima Kwanwoma District of Ghana. This was adopted because of their knowledge in the phenomenon under investigation and the need for them to clarify issues that were seen contradictory. Pupil participants were selected using snowballing approach. Few pupils who were engaged in illegal mining activities were used to reach out to the masses. The parent participants were selected through the simple random 
sampling approach. In this process, households assigned with numbers from the three selected schools were written on slips of papers, mixed thoroughly in a container and drawn as a lottery one after the other until the required number of respondent was obtained.

\section{Research Instrument}

The study employed questionnaire (4-point Likert scale), semi-structured interview, and document analyses in gathering the required data.

\section{Questionnaire}

A questionnaire is a research instrument consisting of series of questions that is administered to generate information about the trends in attitude, opinions, behavior or characteristics of a group of respondents (Creswell, 2012). Questionnaire was the first instrument used to collect data in the study. The questionnaire was used to collect quantitative data on effects of illegal mining on academic performance of junior high school pupils. Kusi (2012) asserted that, most research participants feel more comfortable responding to pre-determined response than items that require them to express their views and feeling. Accordingly, the items on the questionnaire were closeended and required participants to check a box to show their degree of acceptance to each item.

The researchers considered questionnaire as an appropriate instrument for the study due to the fact that it is a common and familiar data collection instrument that is widely used in educational research in teacher knowledge. Similarly, it also serves as a means of minimizing bias and requires less time to administer (Denueme, 2016). Despite the numerous benefits of questionnaires, they also carry with them some challenges. They often have low response rates, cannot delve deep into respondents' opinions and feelings (Alhassan, 2006). Notwithstanding the challenges associated with it usage the researchers weighed the advantages over the challenges and considered it as the best instrument for the collection of quantitative data for the study. The questionnaire consisted of four sections: A, B, C and D. Section A comprised demographic items such as age range, sex and education level. Sections B, C, and D comprised items that used a 4point Likert scale (labeled strongly disagree, disagree, agree, strongly agree) that related to influence of illegal mining on academic performance of pupils.

\section{Semi-Structured Interview}

Being aware that questionnaires alone cannot provide an in-depth understanding of the phenomenon, interviews were also conducted. According to Creswell (2012) an interview is an interactive process between a researcher and a subject in which the researcher poses a question and records answers supplied by the subject. Denscombe (2010) identified three categories of interviews namely; structured interview, semi-structured interview and unstructured interview. In this study, a semi-structured interview was used to collect qualitative data on the influence of illegal mining on academic performance of junior high school pupils. The interview guide was designed based on emergent issues from literature. Four Parents, and four pupils in this study were also interviewed with the help of interview guide. 


\section{Documentation}

The study also dwelled on secondary sources of data, mainly data that already existed. The researchers reviewed documents on pupils' academic performance. Pupils' performance in Social Studies subject in the second term was also reviewed to capture their academic performance. Kusi (2012) described document as a good place to search for answers, which also provide an effective means of checking primary data gathered through interviews. The use of these document help to augment other data sources and enabled us to crosscheck details of pupils' academic performance obtained in the questionnaire and interviews as a form of triangulation.

\section{Validity and Reliability of the Quantitative Instrument \\ Issue of Validity \\ Validity refers to the extent to which the instrument accurately measures a desired concept in a quantitative study (Tavakol \& Dennik, 2011). In determining the content validity of the survey questionnaires, the researchers presented the drafts to senior colleague lecturers at the University of Education, Winneba to assess the questions. This is because, the inputs of senior lecturers are vital in determining content validity since it relies on expert judgment.}

\section{Issue of Reliability}

Reliability relates to the consistency of a measure (Tavakol \& Dennik, 2011). In ensuring reliability, the researchers piloted the study among pupils and parents who were not part of the selected sample. The internal reliability of the questionnaire was determined with the help of the Statistical Product and Service Solution (SPSS) version 20. According to Tavakol and Dennik (2011), Cronbach's alpha is an important and most common means of evaluating the internal consistency of a research statistical instrument. Kothari (2004) offered the following guidelines regarding interpretation of Cronbach's alpha scores: $\geq 0.9$ is excellent, $\geq 0.8$ is good, and $\geq 0.7$ is acceptable, $\geq 0.6$ is questionable, $\geq 0.5$ is poor, and $\leq 0.5$ is unacceptable. Using this guide of the Cronbach's alpha score, the reliability test results of the research instrument yielded 0.72 which is acceptable.

\section{Trustworthiness of the Qualitative Study}

Trustworthiness is used to evaluate the worth of the qualitative data. To establish the trustworthiness of a qualitative study researchers, have to ensure: credibility, transferability, dependability and confirmability of qualitative findings (Gall, Gall \& Borg, 2007). In this study the researchers adopted Gal et al. (2007) model of establishing trustworthiness as a means of evaluating the worth of the study. The model was adopted due to the fact that it is developed conceptually and is widely used by qualitative researchers.

\section{Pilot Study}

Pilot study is a preliminary study conducted to help researchers make informed decisions about a major project (Crossman, 2017). The outcome of a pilot test enables the researcher to recognize, and to rectify problems, ahead of the main research being conducted (Eiselen \& Uys, 2005). Accordingly, the researchers piloted the study among a group of ten pupils in two Junior High Schools and five of their parents in Atwima Kwanwoma District in the Ashanti Region of Ghana. 
The sample size for the pilot study represented $14 \%$ of the actual sample for the study. The researchers chose these schools in the same district because it has similar characteristics to the setting of the study, such as teaching time-table, teaching and learning resources, and mining resources. The pilot-study provided room to enhance the validity and reliability of both the questionnaire and the interview guide. Awanta and Asiedu-Addo (2008) conceived pilot testing of instruments as a window which enabled researchers to modify items that were difficult to understand, reduce ambiguities and incorporate new categories of responses that were identified as relevant to the study.

\section{Data Collection Procedure}

The questionnaire administration spanned four weeks, and were delivered to the respective schools personally by the researchers for the pupils to respond to them. This was after permission had been sought and granted by the District Directorate of Education with a letter of introduction from the Department of Basic Education, University of Education. Upon reaching the schools, the researchers went to the head teachers to introduce themselves and sought permission by handing over the letter of authorization from the District Education Office before administering the questionnaire. The researchers visited the schools that were involved in the study to administer the instrument to the pupil respondents concerned. Parent participants were however visited at their homes for the collection of data as agreed upon. The instruments were administered to all the sampled schools in four weeks. In order to ensure that the instruments were well completed, enough time was given to the pupils so that they could have time to complete them well. The return rate for the instrument was $100 \%$ since its administration was personally done by the researchers.

\section{Method of Data Analysis}

With the aid of Statistical Product and Service Solution (SPSS) software, descriptive statistics such as frequency counts, percentages and the mean and standard deviation were employed to analyse the questionnaire. The researchers also used thematic analysis to analyse the qualitative data collected using the interview guide. Quantitative data from the questionnaire were analysed using descriptive statistics with the help of SPSS version 20. It was used to summarize and transform quantitative data into frequencies, percentages, means and standard deviations for answering of the research questions. The use of descriptive statistics according to Denscombe (2010), do not only allow researchers to use numbers but also provide them with data that create room for inferences on the population and directions for answering research questions. An itemby-item analysis of data was conducted. The percentage of the total respondents responding to each question was stated with their means and standard deviations calculated. The questionnaire had its scales of measurement reduced from 4-point Likert scale to 2-point Likert scale for easy analysis of the data. For instance, the researcher combined "Strongly Disagree" and "Disagree" to Disagree and "Strongly Agree" and "Agree" to Agree. The study also used thematic analysis to analyse the qualitative data collected using the interview guide. 


\section{Results and Discussion}

\section{Demographic Characteristics of Participants}

The demographic compositions of the respondents were examined, and the results are presented in Table 2.

\begin{tabular}{llcc}
\hline Variables & Category & Frequency & Percentage \\
\hline Participants & Parents & $\mathbf{3 5}$ & $\mathbf{3 3 . 3}$ \\
& Pupils & $\mathbf{7 0}$ & $\mathbf{6 6 . 7}$ \\
Sex of Pupils & Total & $\mathbf{1 0 5}$ & $\mathbf{1 0 0}$ \\
& Male & 48 & 69 \\
& Female & 22 & 31 \\
Age of Pupils & Total & $\mathbf{7 0}$ & $\mathbf{1 0 0 . 0}$ \\
& $10-13$ & 22 & 31 \\
Sex of Parents & $14-17$ & 45 & 64 \\
& 18 and above & 3 & 4 \\
Age of Parents & Total & $\mathbf{7 0}$ & $\mathbf{1 0 0 . 0}$ \\
& Male & 10 & 29 \\
& Female & 25 & 71 \\
& Total & $\mathbf{3 5}$ & $\mathbf{1 0 0 . 0}$ \\
& $31-40$ & 8 & 23 \\
Parents Educational Background & Formal Education & 1 & 74 \\
& Non-formal Education & $\mathbf{2 8}$ & 3 \\
& Total & $\mathbf{3 5}$ & $\mathbf{1 0 0 . 0}$ \\
& & & $\mathbf{1 0 0}$ \\
\hline
\end{tabular}

As indicated in Table 2, more pupils $(n=70,66.7 \%)$ than parents $(n=35,33.3 \%)$ were involved in the study. The information further revealed that more male pupils $(n=48,69 \%)$ than female pupils $(n=22,31 \%)$ were involved in the study. The information further revealed that more than half of the pupils were between 14-17years $(n=45,64 \%)$ than those who fell between 10-13years $(n=22,31 \%)$ while the rest were those who were 18years and above $(n=3,4 \%)$. Concerning sex of the parents, the findings showed that most of the parents who participated in the study were females $(n=25,71 \%)$ than males $(n=10,29 \%)$. The age distribution of the parents disclosed that, parents between the 41-50 years $(n=26,74 \%)$ were more than those between $31-40(n=8,23 \%)$ as well as those who were 50 years and above $(n=1,3 \%)$. The distribution of the parents on their educational background revealed that majority of the parents $(n=28,80 \%)$ had no education than those with formal education $(n=7,20 \%)$. The demographic distributions of the respondents were crucial to the study because they showed that data were collected from respondents with diverse backgrounds, thereby making the data rich and devoid of bias. In this way, the authenticity of the data and their findings were enhanced. 


\section{Research Question:}

To what extent do illegal mining activities influence the academic performance of junior high school pupils in Atwima Kwanwoma District in the Ashanti Region of Ghana?

In relation to the research question, the study aimed at gathering data on how illegal mining activities contributed to pupils' academic performance in junior high schools using questionnaire. Table 3 details the results as follows:

\section{Table 3: Descriptive Statistics of the Effects of Illegal Mining Activities on Pupils' Academic Performance}

\begin{tabular}{|c|c|c|c|c|c|c|c|c|c|c|c|c|}
\hline \multirow{3}{*}{ ITEMS } & \multicolumn{6}{|c|}{ PUPILS } & \multicolumn{6}{|c|}{ PARENTS } \\
\hline & \multicolumn{2}{|c|}{ D } & \multicolumn{2}{|c|}{$\mathbf{A}$} & \multirow[b]{2}{*}{$\mathbf{M}$} & \multicolumn{3}{|c|}{ D } & \multicolumn{2}{|c|}{$\mathbf{A}$} & \multirow[b]{2}{*}{$\mathbf{M}$} & \multirow[b]{2}{*}{ SD } \\
\hline & No. & $\%$ & No. & $\%$ & & SD & No. & $\%$ & No. & $\%$ & & \\
\hline $\begin{array}{l}\text { 1. The time pupils spend in engaging } \\
\text { mining activities affects their academic } \\
\text { studies. }\end{array}$ & 18 & 26 & 52 & 74 & 1.74 & 0.48 & 2 & 6 & 33 & 94 & 1.94 & 0.51 \\
\hline $\begin{array}{l}\text { 2. The work of children at the mining site } \\
\text { has adverse effect on academic } \\
\text { performance. }\end{array}$ & 5 & 7 & 65 & 93 & 1.93 & 0.51 & 12 & 34 & 23 & 66 & 1.66 & 0.50 \\
\hline $\begin{array}{l}\text { 3. Pupils are unable to complete assignment } \\
\text { due to their engagement in mining } \\
\text { activities }\end{array}$ & 15 & 21 & 55 & 79 & 1.79 & 0.50 & 10 & 29 & 25 & 71 & 1.71 & 0.50 \\
\hline $\begin{array}{l}\text { 4. Academic performance has been } \\
\text { enhanced partly due to the fact that } \\
\text { pupils are able to buy some basic } \\
\text { necessities from the monies they acquire } \\
\text { from mining operation. }\end{array}$ & 34 & 49 & 36 & 51 & 1.51 & 0.42 & 4 & 11 & 31 & 89 & 1.89 & 0.33 \\
\hline $\begin{array}{l}\text { 5. Pupils cannot comprehend lessons taught } \\
\text { in class due to tiredness emanated from } \\
\text { their engagement in mining activities. }\end{array}$ & 6 & 9 & 64 & 91 & 1.91 & 0.45 & 9 & 26 & 26 & 74 & 1.74 & 0.45 \\
\hline
\end{tabular}

Source: Field Data (2019). Key: f-Frequency, \%-Percentage, $M$-Mean, $S D$-Standard Deviation, $\mathrm{D}=\mathrm{Disagree}, \mathrm{A}=$ Agree

Data from Table 3 shows that pupils' mean scores ranged from 1.51 to 1.93 and standard deviation from 0.42 to 0.51 . This means that, most of the pupils on average admitted that illegal mining activities have contributed to their academic performance. For example, $52(74 \%)$ of the pupil participants conceded to the statement that 'the time pupils spend in engaging mining activities affects their academic studies.' while $18(26 \%)$ of them disagreed to the statement with a mean score of 1.74 and standard deviation of 0.48 . This indicates that, the time pupils spend in engaging mining activities affects their academic studies as admitted by majority of pupil participants. Moreover, $55(79 \%)$ of the pupil participants agreed to the statement that 'pupils are unable to complete assignment due to their engagement in mining activities.' whereas 15 (21\%) of them declined to the statement with a mean score of 1.79 and a standard deviation score of 
0.50. The indication is that, most of the pupils acknowledge that they are unable to complete assignment due to their engagement in mining activities.

In the case of the parent participants, the mean scores ranged from 1.66 to 1.94 and standard deviation from 0.33 to 0.51 . This means that, majority of parents on average conceded that illegal mining activities have contributed to pupils' academic performance. From Table 4.4 for instance, 33 (94\%) of the parent participants conceded to the statement that 'the time pupils spend in engaging mining activities affects their academic studies.' whereas 2 (6\%) of them disagreed to the statement with a mean score of 1.94 and standard deviation of 0.50 . This means that, most of the parent participants hold the view that the time pupils spend in engaging mining activities affects their academic studies. Also, 25 (71\%) of the parent participants admitted that pupils are unable to complete assignment due to their engagement in mining activities whereas $10(29 \%)$ of them declined to the statement with a mean score of 1.71 and standard deviation of 0.50. This means that, most of the parent participants believe that there are pupils are unable to complete assignment due to their engagement in mining activities.

\section{Ho1: There is no statistically significant difference between illegal mining activities and pupils' academic performance in Atwima Kwanwoma District in the Ashanti Region}

In testing this hypothesis, multiple regression was used and the results are shown in Table 4.

Table 4: Multiple Regression and ANOVA Results for Illegal Mining and Pupils Academic Performance

\begin{tabular}{|c|c|c|c|c|c|c|c|c|}
\hline \multirow[t]{2}{*}{ Model } & & \multicolumn{2}{|c|}{$\begin{array}{l}\text { Unstandardized } \\
\text { Coefficients }\end{array}$} & \multirow{2}{*}{$\begin{array}{c}\text { Standardized } \\
\text { Coefficients } \\
\text { Beta }\end{array}$} & \multirow[t]{2}{*}{$\mathrm{t}$} & \multirow[t]{2}{*}{ Sig. } & \multicolumn{2}{|c|}{$\begin{array}{l}\text { Collinearity } \\
\text { Statistics }\end{array}$} \\
\hline & & $\mathrm{B}$ & Std. Error & & & & Tol. & VIF \\
\hline \multirow[t]{2}{*}{1} & (Constant) & 41.90 & 11.14 & & 3.76 & 0.000 & & \\
\hline & Illegal Mining & 0.81 & 0.090 & 0.72 & 6.92 & 0.000 & 0.890 & 1.080 \\
\hline $\mathrm{R}$ & 0.78 & & & & & & & \\
\hline $\mathrm{R}^{2}$ & 0.75 & & & & & & & \\
\hline Adj. $R^{2}$ & 0.65 & & & & & & & \\
\hline $\mathrm{F}$ & 3.22 & & & & & & & \\
\hline $\mathrm{P}$ & 0.00 & & & & & & & \\
\hline
\end{tabular}

a. Dependent Variable: Academic Achievement

b. Predictors: (Constant), Illegal Mining Activities

Source: Field work Data (2019)

The multiple regression results as in Table 4 revealed that illegal mining activities collectively accounted for $75 \%$ in variance to pupils academic performance which was assessed to be statistically significant $[\mathrm{F}(1,69)=3.22, \mathrm{p}=0.000]$. This result implied that other factors not 
included in this study could contribute $25 \%$ to pupils' academic performance. Based on these results, it could be concluded that together, illegal mining activities are good predictors of pupils' academic performance. Hence, an increase in illegal mining activities stifles pupils' academic performance

The researcher through the interview also explored on the influence of mining activities on pupils' academic performance. Judging from the responses given by pupils in the interview, it was revealed that mining activities has negatively influenced school attendance and academic performance among pupils. This is depicted by the comments made by some pupil participants that:

\section{"Attendance has reduced and academic performance has become poor since galamasey was introduced in the community. Most of us don't respect our parents and teachers anymore" (S1). \\ "It has caused school dropout as most of us wish to get quick money. In the case of girls, many have dropped out due to the incidence of pregnancy." (S3)}

The quotes from pupil participants show the attendance of pupils and dropout make it extremely difficult for pupils to study eventually reflecting in their academic performance.

From the accounts of parent participants, it was revealed that mining activities has caused pupils to be irregular in school and consequently resulted in their poor academic performance. This is captured in the following excerpt:

"They are not regular in school and that has led to poor academic performance. Even, some dropout from school due to pregnancy." (P2).

Another parent respondent similarly recounted:

"Pupils don't go to school regularly, and due to that they fail in their examination. Others get impregnated by the boys and dropout of school." (P3).

The quotes above from parents' perspective support the view earlier made by pupils that irregular attendance and dropout enacting from mining operations led to poor academic performance.

Again, the study explored participants' views on whether the advent of mining activity in the community has helped education in the district. From the analysis of the interview results, it was revealed among pupils that illegal mining activity in the area has not helped in improving education due to its adverse effects such as poor school attendance, school dropout and poor academic performance. One of the pupils shared his/her experience in the following excerpt: 
"It has not really helped education because, since the advent of mining activities, most children do not attend school but, they are always seen at the [mining] site." (S1).

Similarly, another respondent also recounted:

"Not at all. Because we spend more time looking for money at the site than to study and that has reduced attendance and performance in school. Some girls even get impregnated and they dropout from school." (S4).

The quotes from above show that mining activities have adversely affected the education in the district due to the lack of financial support at home, school dropout, irregular attendance and teenage pregnancy.

From the account of parent participants, it was revealed that pupils do not have time to study due to their involvement in illegal mining activity in the area and that has not helped education at all. This is illustrated in the following excerpts:

"The pupils don't learn nowadays due to galamsey and we can also see most of them dropout from school due to poverty." (P1).

"It is not helping at all. Because the pupils are always at the site in search of money. They don't even have time for studies." (P3).

The above quotes from the parent participants support the view that mining activities have adversely affected education in the district due to pupils search for quick monies which they obtain in through mining activities.

Pupils' academic performance has been defined as the outcome of education and the degree to which a pupil has attained the objectives of his/her institution (Agarana \& Ehigbochie, 2015). In the literature, a lot of analyses have been carried out on how different factors affect pupils' academic performance. Among these are socio-economic and environmental factors such as illegal mining. As evident from the present study findings, illegal mining activities contributed statistically significantly to pupils' poor academic performance in Social Studies. The concern here is that, this adverse effect of illegal mining in Social Studies can spread through to other related subjects of study and to the entire education system at large.

Asiedu-Addo (2009) and Howard (1994) in a study proposed several reasons for children's low performance among which are medical problems, below average intelligence, specific learning disability, emotional problems and environmental causes. They believe that to solve this multivaried and cross-linked problem, the focus should move from the class to the family, to the 
environment and to the social world of pupils. From the study, it was revealed that mining activities has caused pupils to be irregular in school and consequently resulted in their poor academic performance. Pupils in the current study through the interview disclosed that, sometimes their parents had to invite them to come and help them at the mining site because that is what they depend on for survival.

These pupils become tired and therefore are unable to make time for studies as a result of their engagement in mining related activities as revealed by the interview. This negatively affects their academic performance in school and quality education in general. This is supported by AduGyamfi's (2014) findings which revealed that illegal mining activities undertaken by pupils do have negative effect on school attendance and academic performance and it was established that pupils who come to school regularly perform tremendously while the absentee pupils perform poorly. He therefore recommended that parents must educate their wards and be aware that it is their responsibility to bear the cost of their children's needs.

\section{CONCLUSION AND IMPLICATION FOR PRACTICE}

There is no doubt that illegal mining provides employment and a means of livelihood for some people in the communities of Atwima Kwanwoma District and similar places in Ghana where unemployment rate is high. Moreover, due to the lucrative nature of illegal mining, people especially young adults are more inclined to partake in illegal mining activities as it was revealed in the study findings. This study considered the influence of illegal mining on academic performance of junior high school pupils in the Atwima Kwanwoma District of the Ashanti Region. After a careful assessment of illegal mining activities among children under schoolgoing age in the Atwima Kwanwoma District, the researchers came to the conclusion that illegal mining is a major contributor to the poor academic performance of junior high school pupils in Social Studies. The study established that despite the efforts made by government to enforce the enrollment of all children under school going age in Free Compulsory Universal Basic Education (FCUBE) policy. The worrying issue, however, is that the adverse effects of illegal mining on education have not yielded the results as we expected since the illegal mining menace continues to plague many spheres of our educational sector. The time has come for more decisive actions to be taken by all to confront the issue of illegal mining among the citizenry especially young children head-on.

\section{RECOMMENDATIONS}

Based on the study findings, the researchers made some recommendations that are directed at helping reduce illegal mining activities and its associated education effects: As evident from the findings, illegal mining activities contributed statistically significantly to pupils' academic performance in Social Studies. There must be an intense public education and sensitization about the dangers of illegal mining operations on pupils' academic performance. To make this effective, the Directorate of Ghana Education Service at Atwima Kwanwoma District and traditional leaders must be in constant dialogue with members of the communities especially 
parents to appreciate the value of formal education in order to ensure that their children stay in school and study. This is because parental involvement in children's education is key for their future successes.

\section{REFERENCES}

Adjei, A. (2017). The impact of illegal mining (galamsey) on cocoa production and livelihood: Acase study of Amansie West District. Unpublished MBA thesis, University of Education, Winneba.

Adu-Gyamfi, E. (2014). The effect of illegal mining on school attendance and academic performance of junior high school pupils in Upper Denkyira West District of Ghana.Journal of Education \& Human Development, 3(1), 523-545.

Akabzaa, T. (2007). African mining codes, a race to the bottom. African Agenda, 7 (3), 62-63.

Alhassan, S. (2006). Modern approaches to research in education administration for research students. Amakom, Kumasi: Payless Publication Ltd.

Amankwah, R. K., \& Anim-Sackey, C. (2003). Strategies for sustainable development of smallscale gold and diamond mining industry of Ghana. Resource Policy, 29, 131-138.

Ankutse, B. (2015). Assessing the effects of mining on the educational life of children in the Asutifi District in the Brong Ahafo Region of Ghana. Unpublished master's thesis, Kwame Nkrumah University of Science and Technology, Kumasi, Ghana.

Annan, D. A. (2015). Effects of galamsey on education in mining communities. Retrieved from https://www.newsghana.com.gh/effects-of-galamsey-on- education-in-miningcommunities/ on 06/09/2018.

Anney, V. N. (2014). Ensuring the quality of findings of qualitative research: Looking at trustworthiness criteria. Journal of Emerging Trends in Educational Research and Policy Studies (JETERAPS), 5(2), 272-281

Asamoah-Gyimah, K., \& Duodu, F. (2007). Introduction to Research Methods in Education University of Education, Winneba: Institute for Educational Development and Extension (IEDE).

Asiedu-Addo, S. (2009). Why many pupils in Central Region fail in the BECE? Daily Graphic, Saturday, October 10, 2009.

Awanta, E. K., \& Asiadu-Addo, S. K. (2008). Essential statistical research for universities, colleges and research institutions. Accra: Salt and Light Publishers.

Cohen, L., Manion, L., \& Morrison, K. (2007). Research methods in education. London: Routledge/Falmer.

Creswell, J. W. (2012). Educational research: Planning, conducting and evaluating quantitative and qualitative research (4th ed.). Boston: Pearson.

Crossman, A. (2017). Pilot Study. Retrieved from What Pilot Studies Are and Why They Matter - ThoughtCo. Retrieved from https://www.thoughtco.com > .. > sociology > Key Theoretical Concepts. On 20/09/2018

Diaz, A. L. (20030. Personal, family and academic factors affecting low achievement in secondary school. Electronic journal of research in educational psychology and psychology 1(1), $43-66$. 
Denscombe, M. (2010). Research guide for small-scale social research projects (4th ed.). New York: Open University Press.

Denueme, K. (2016). Teacher motivation factors and their effect on the job performance of basic school mathematics teachers in the Awutu Senya West District of the Central Region of Ghana. University of Education, Winneba, Ghana.

Eiselen, R. J., \& Uys, T. (2005). Questionnaire design. Johannesburg: University of Johannesburg

Ellis, F. (2000). Rural livelihoods and diversity in developing countries. Oxford, England: Oxford University Press.

Gall, M. D., Gall, J. P., \& Borg, W. R. (2007). Educational research: An introduction (8th ed.). Needham Heights MA: Allyn \& Bacon

Hilson, G., \& Potter, C. (2003). Why is illegal gold mining activity so ubiquitous throughout rural Ghana? African Development Revue 15 (2), 237-270.

Iddirisu, A. Y., \& Tsikata, F. S. (1998). Mining sector development and environment project. Regulatory framework study to assist small-scale miners. Study prepared for the Minerals Commission. Accra: Minerals Commission.

Kothari, R. C. (2004). Research methodology: Methods and techniques. New Delhi: Wiley Eastern Limited.

Kusi, H. (2012). Doing qualitative research, a guide for researchers. Accra: Emmpong Press.

Maslow, A. (1971). The farther reaches of human nature. New York: The Viking Press.

McMillan, J. H., \& Schumacher, S. (2010). Research in education: Evidence-based inquiry ( $7^{\text {th }}$ ed.). New York, NY: Pearson.

Owusu, E. E., \& Dwomoh, G. (2012). The impact of illegal mining on the Ghanaian youth: Evidence from Kwaebibirem District in Ghana. Research on Humanities and Social Sciences, 2(6), 86-92.

Tavakol, M., \& Dennik, R. (2011). Making sense of Cronbach's alpha. International Journal of Medical Education, 2, 53-55.

Yin, R. K. (2014). Case study research: Design and methods (5 $5^{\text {th }}$ ed.). Thousand Oaks, CA: Sage. 